\title{
Climate change, energy and social preferences on policies: exploratory evidence for Spain
}

\author{
Michael Hanemann ${ }^{1}$, Xavier Labandeira ${ }^{2,3}$, Maria L. Loureiro ${ }^{4, *}$ \\ ${ }^{1}$ Department of Agricultural \& Resource Economics, University of California, Berkeley, California 94720-3310, USA \\ ${ }^{2}$ Rede, University of Vigo, 36310 Vigo, Spain \\ ${ }^{3}$ Economics for Energy, 36202 Vigo, Spain \\ ${ }^{4}$ Departamento de Fundamentos da Análise Economica, Facultade de CC Económicas, Avda. do Burgo das Nacións, \\ 15782 Santiago de Compostela, Spain
}

\begin{abstract}
Spain faces a complex situation regarding its climate change policies. On the one hand, greenhouse gas emissions have shown an important increase since 1990, and are far above the Kyoto commitments. On the other hand, the country is likely to suffer significant impacts from climate change. To date, however, there has been a rather limited application of corrective policies, particularly with regard to energy prices. Indeed, although Spanish citizens are generally very concerned about climate change, price increases in the energy sector have traditionally been opposed. In the present paper, we offer suggestions for future policies, showing that Spanish households, in general, are strongly in favour of the implementation of a green electricity program, which reduces greenhouse gas emissions, although it makes electricity more expensive for an interim period. Data from a telephone survey representative of the Spanish population which we carried out immediately prior to the Copenhagen climate summit, show that people were willing on average to pay an increase of $29.91 €$ per month per household over the current electric bill. Our results also show that younger individuals living in the Mediterranean area are more likely to pay for this green electricity program.
\end{abstract}

KEY WORDS: Electricity $\cdot$ Climate change $\cdot$ Willingness to pay $\cdot$ Spain

\section{CONTEXT}

Climate change has become a major concern for citizens around the world. The first world-wide global warming survey of a large international pool of people was conducted by World Wide Views (2009). This shows that the vast majority of people (close to $90 \%$ ) favouring sizeable reductions in greenhouse gas (GHG) emissions for developed countries in the period from 1990 to 2020. A similar proportion of citizens strongly supports keeping global warming within $2{ }^{\circ} \mathrm{C}$ over preindustrial levels. In Europe, Eurobarometer (2009) indicates that two-thirds of the European population consider global warming to be among the most serious problems facing mankind today. Although there are geographical differences within Europe, Spain is one of the countries well above the EU average in rating climate change as a very serious problem. At the same time, most Europeans (again, roughly two-thirds) believe that governments and industries are not doing enough to fight the problem.

This is the general setting of the present paper: intense social preferences for climate-change abatement that have not been fully materialized in actual policy-making. In this sense, Spain is probably quintessential, with a strong concern on the part of both citizens and the government (1 of 3 'guiding issues' of the current Spanish government), but few implemented policies. In a way, Spain faces a complex situation regarding its climate-change policies. On the one hand, GHG emissions have increased significantly since 1990 (by around $30 \%$ at the time of writing, with a recent sharp reduction due to the recession) and are, thus, far higher than the Kyoto commitment (15\% 
increase). On the other hand, Spain is likely to suffer substantial impacts from climate change due to its geographical situation: significant temperature increases and an exacerbation of water shortages are to be expected in a few decades (Spanish Agency of Meteorology 2010). However, there has been limited application of corrective policies, particularly in the area of energy prices, which are generally below European averages.

This fact is in contrast with the traditional support of economists in using pricing instruments to effect climate policy. Carbon prices, for instance, are seen as a necessary mechanism to achieve cost-effective abatement and to foster carbon-free technologies. Yet, in Spain, carbon pricing has traditionally been opposed by governments, despite the growing evidence of its positive effects. Fear of loss of competitiveness led successive Spanish governments to block all attempts at setting a European-wide carbon tax during the 1990s and early 2000s, despite empirical evidence showing that a Spanish green tax, based on carbon taxation, could lead to net economic gains (Labandeira et al. 2004), with limited distributional consequences (Labandeira \& Labeaga 1999).

Is there any reason for this reluctance, despite the likely positive effects of the policy and the underlying social preferences regarding climate change? The intense opposition of Spanish citizens to tax-related price increases of car fuels over the past decade or the strong pressure to keep electricity prices low (with a clear risk to the financial sustainability of the electricity system, which is now operating at a deficit as prices do not cover costs) may provide intuitive explanations for the lack of corrective carbon pricing. As indicated below, the focus groups used in the preliminary stages of this study were consistent with this behaviour.

Our study involves an application of contingent valuation $(\mathrm{CV})$, using a survey that asks respondents to state their willingness to pay (WTP) in support of a policy initiative that reduces Spain's GHG emissions from electricity production. There is a growing body of literature on the WTP for climate-change policies, with recent contributions by Berrens et al. (2004), Stedman (2004), Cameron (2005a,b), Li et al. (2005), Leiserowitz (2006) and Lee \& Cameron (2008). These papers reflect the perceptions towards various climate-change policies in many different countries, mostly through the use of CV methods. Other approaches include discrete choice experiments (Longo et al. 2008) and ordinal responses to valuation scenarios (Diaz-Rainey \& Ashton 2007). The policy objectives, or environmental goods under consideration, also vary considerably among the papers and include climate-stabilizing measures (Cameron 2005b), green energy investments (Diaz-Rainey \& Ashton 2007, Wiser 2007, Hoyos \& Mar- kandya 2009), decreased temperature changes (Viscusi \& Zeckhauser 2006) and sequestration mechanisms (Brouwer et al. 2008). For a comprehensive review of the literature see Johnson \& Nemet (2010).

Although the applications of $\mathrm{CV}$ methodology for Europe are still limited, they have grown considerably in recent years. For instance, Cole \& Brännlund (2009) assessed preferences for mitigation policies in Sweden, showing that citizens in Sweden support informational campaigns, as well as measures that have positive effects on technological development. In Spain, Hoyos \& Markandya (2009) investigated preferences for climate-change measures in the Basque region, including global (as in previous studies) and ancillary benefits. They showed that estimates are $40 \%$ higher when ancillary benefits are also included.

The present paper contributes to the European literature on climate-change policy. While the CV method has been used in other studies to value the non-market impacts associated with climate change, our study uses it to deal directly with the design of mitigation policy. We focus on GHG emissions from the electricity sector, which is the largest single source of Spanish GHG emissions and has been subject to intense debate on pricing in recent years. Moreover, in the past decade Spain has embarked on a very ambitious and costly venture to promote renewable sources in the electricity sector (intended, in part, to abate GHG emissions), the characteristics of which are probably well known to its citizens.

The present paper is based on a phone survey of a representative sample of the Spanish population, conducted in November and December 2009 (immediately prior to the Copenhagen summit). The results show that Spanish households would strongly favour the adoption of an electricity policy that would make electricity more expensive, but that would use the extra revenue to promote renewable energy to reduce GHG emissions. In particular, the average WTP per month and household is large: an increase of €29.91 over the current electric bill. Our results also show that younger individuals who live in the Mediterranean area are more likely to be willing to pay for this green electricity program. The evidence from the present paper may provide some guidance for future pricing policies aimed at climate-change control.

\section{QUESTIONNAIRE AND VALUATION SCENARIO}

Our research method relies on the construction of a questionnaire to assess preferences with respect to climate change mitigation policies in Spain. Several stages were required to produce a comprehensive and easy survey instrument. To begin with, discussion with focus groups were carried out in several Spanish cities, 
including A Coruña (coastal) and Santiago de Compostela and Madrid (inland areas). The focus groups contained 10 to 12 individuals with different socioeconomic profiles, who participated in $2 \mathrm{~h}$ of organized discussion about the magnitude of the climate-change problem and things that could be done in Spain by way of a solution. Information obtained from the first focus group on attitudes regarding climate change was utilized to design a draft version of the questionnaire, which was then tested and modified in subsequent focus groups. The final version of the questionnaire reflects information obtained from 5 different focus groups.

The questionnaire follows the same basic structure as that in Malka et al. (2009), adapted to the Spanish socio-economic context. The questionnaire first poses questions about a variety of social issues, such as taxes, unemployment and pollution. Next, specific questions are asked about the respondent's familiarity with climate change and his/her perception of the damage caused by climate change. The questionnaire continues by describing some options the Spanish government is considering to reduce GHG emissions, including an electricity program. ${ }^{\mathbf{1}}$ It was stressed that the objective of this electricity program is to fulfil the Spanish 20/20/20 objectives with respect to emission levels in Spain (that is, 20\% reduction in GHG emissions, $20 \%$ renewable energies and $20 \%$ improvement in energy efficiency by 2020). Our goal was to measure the social preference for this program, in terms of willingness to pay the program's cost. Our intent was to provide some guidance for mitigation policy in Spain, rather than to evaluate the damages resulting from climate change. Since Spain can control its own GHG emissions, but it cannot control global GHG emissions, and, therefore, it cannot control the specific impacts from climate change that might be felt in Spain, we believed this was a more appropriate focus for the CV questionnaire. After the payment question, there were questions about the reasons for the response to the payment question. These were followed by questions about attitudes toward the national and global policies to deal with climate change. The questionnaire concluded with several socio-demographic questions.

With regard to the payment scenario, the cost of the climate-change mitigation program was described as a private cost linked to an 'extra electricity price per month'. The following wording was used:

\footnotetext{
${ }^{1}$ Due to the large degree of uncertainty, no information was provided for expected climate-change avoidance effects linked to the fulfillment (as against non-fulfillment) of the 20/20/20 objectives. However, individuals revealed through various questions their level of knowledge, concern, awareness and commitment to fight climate change.
}

The electricity we use in our homes and factories is the single largest source of greenhouse gas emissions in Spain. This accounts for $28 \%$ of Spain's greenhouse gas emissions.

The Spanish government is considering taking action to reduce the greenhouse gas emissions caused by electricity generation and consumption. The Spanish government is considering a balanced program to reduce the energy we use in our homes and factories. This program includes requiring power companies to make electricity in ways that do not emit greenhouse gases, such as renewable energies. Also, the government will require factories to use highly efficient energy equipment, and to manufacture products which meet climate requirements. The government will continue to regulate the price of electricity for households, so that electricity companies cannot make excessive profits.

In the end, this program will make electricity less expensive to produce, but for an initial period of some years, the price of electricity will be higher. In the end, cleaner technologies and higher energy efficiency will make the cost of living lower and electricity less expensive.

If the government goes ahead with this program, the extra cost to your household is likely to be \$X per month (or Y per year) until about 2020. Would you be in favour of this program?

YES NO DON'T KNOW

The survey was implemented via phone in all Spanish territories, including the Balearic and Canary Islands. The survey employed a multi-stage sample, first selecting different population areas in each region (autonomous community), including large, medium and small cities, and then using random digital dialling. In the following analysis all responses are included, even those that may be considered protest responses. This seems appropriate since in a real election all votes will count. There was considerable awareness of climate change at the time of the survey because of the publicity given to the Copenhagen summit on climate change in the weeks prior to the survey. The average time taken to complete the survey was $8 \mathrm{~min}$.

\section{SAMPLE AND ECONOMETRIC MODELLING}

With respect to the characteristics of the sample, the average age was $44.7 \mathrm{yr}$, and $48 \%$ of respondents were male. Most respondents were employed full-time (35.5\%), while retired respondents amounted to $18.4 \%$, and the self-employed and those working at home represented 10.7 and $10.5 \%$, respectively. With respect to the number of income contributors to the household, $42.3 \%$ of the households had 2 income earners, while $34.7 \%$ had only 1 income earner. Given the large number of people in each Spanish household, 9.21 and $13.6 \%$ had 3 and 4 or more income earners, respectively.

The average education level in the sample was about the census average, with 26.8 and $29.4 \%$ of the individuals having completed high school and elementary 
school, respectively. If we compare our data with the census, we find no significant differences with respect to the basic education level, since $37.4 \%$ of the adult Spanish population has completed elementary school. In addition, $13.9 \%$ of the respondents had completed high school, and $18.5 \%$ a university degree, in comparison to 20.7 and $21.8 \%$, respectively, in the Spanish census. No significant differences were found either with respect to age or gender composition, the average age in the Spanish population being $40.2 \mathrm{yr}$ in 2006 (compared to $47.7 \mathrm{yr}$ in our sample), and about $49.42 \%$ of the population was male (about $57 \%$ were male in our sample). Finally, with respect to the place of origin, in both our sample and the census, the population was concentrated along the coast, with nearly $27 \%$ living inland. Thus, a number of social and demographic variables show that our sample is representative of Spanish households (Table 1).

In the following statistical analysis, WTP responses in the category 'do not know' or 'no answer' were recorded as negative responses. This procedure was employed by Carson et al. (2003), and is one element which makes our WTP estimates conservative.

Responses to the WTP question were analyzed with a probit model. The statistical model for the valuation response takes the following functional form:

$$
\begin{gathered}
Y^{*}=\beta_{0}+\beta_{1} \text { Bid }_{i}+\beta_{2} \text { Age }_{i}+ \\
\beta_{3} \text { Mediterranean }_{i}+\beta_{4} \text { Inland }_{i}+\beta_{5} \text { MidIncome }_{i}+ \\
\beta_{6} \text { HighIncome }_{i}+\beta_{7} \text { ElectricBill }_{i}+\varepsilon_{i}
\end{gathered}
$$

where $Y^{*}$ is the latent variable representing participants' preferences for the electricity program and the right-hand side contains explanatory variables and an error term that is assumed to follow a standard normal distribution.

The explanatory variables are: the 'Bid', which reflects the price increment to be paid (randomly selected from a vector of $€ 5,10,16,25$ and 40 values) if the electricity program is implemented; 'Age' is the respondent's age; 'Mediterranean' and 'Inland' indicate whether the respondent lives on the Mediterranean coast or in the interior of the country (location on the Cantabrian coast was the omitted category). Additionally, the dummy variables 'MidIncome' and 'HighIncome' represent household monthly incomes between $€ 1500$ and $€ 2999$ and incomes of $€ 3000$ or above (income below $€ 1500$ was the omitted category), respectively. The variable 'ElectricBill' represents the current monthly household electricity payment. Table 2 lists the explanatory variables and gives the means \pm SD. Table 3 presents estimated coefficients of Eq. (1) based on the survey responses and employed to calculate the mean WTP estimate.

As reflected in Table 3, results from the probit model indicate that, as economic theory predicts, the sum
Table 1. Basic sample characteristics compared with the Spanish census by the Instituto Nacional de Estadística (INE) in 2005

\begin{tabular}{|c|c|c|}
\hline Variables & $\begin{array}{l}\text { Sample mean } \\
\text { or } \%\end{array}$ & $\begin{array}{l}\text { Spanish } \\
\text { census }\end{array}$ \\
\hline Gender (= 1 if male) & 56.9 & 49.4 \\
\hline Age & 47.7 & 40.2 \\
\hline \multicolumn{3}{|l|}{ Education } \\
\hline Illiterate & 2.86 & \\
\hline Elementary school & 26.1 & $\begin{array}{c}37.4 \text { (elementary } \\
\text { or lower) }\end{array}$ \\
\hline $\begin{array}{l}\text { High school/ } \\
\text { professional education }\end{array}$ & 39.5 & 40.5 \\
\hline University degree & 28.8 & \\
\hline Postgraduate and $\mathrm{PhD}$ & 1.6 & \\
\hline \multicolumn{3}{|l|}{ Annual income (2005) } \\
\hline Up to $€ 5999$ & 2.98 & 7.6 \\
\hline$€ 6000-11999$ & 11.5 & 20.7 \\
\hline$€ 12000-17999$ & 29.8 & 25.1 \\
\hline$€ 18000-23999$ & 18.3 & 19.9 \\
\hline$€ 24000-29999$ & 11.5 & 13.0 \\
\hline$€ 30000-35999$ & 11.5 & 6.3 \\
\hline$€ 36000-59999$ & 13.5 & 6.1 \\
\hline More than $€ 60000$ & 1.0 & \\
\hline \multicolumn{3}{|l|}{ Occupation } \\
\hline $\begin{array}{l}\text { Self-employed/full-time/ } \\
\text { part-time employee }\end{array}$ & 51.0 & \\
\hline Without job/looking for job & 10.3 & \\
\hline Student & 4.7 & \\
\hline Household work & 11.5 & \\
\hline Retired & 17.8 & \\
\hline Other & 4.3 & \\
\hline
\end{tabular}
and 2006 (data available at: www.ine.es/inebmenu/mnu cifraspob.htm). Data are given in \% except age, which is a mean

which respondents have to pay has a negative effect on the probability of their supporting the electricity program. Further, individuals living in the Mediterranean and southern areas are more likely to be willing to pay for the green electricity program than those living in the Cantabrian or northern area. This may be related to the fact that the impact of climate change is anticipated to be greater in the Mediterranean and southern areas. Additionally, individuals who are older are also less likely to be willing to pay for the program. The income variables are not statistically significant. The current monthly electricity bill does affect the WTP for the program in a negative and statistically significant way. Thus, our results show that younger citizens without family obligations and with low electricity bills are the ones more likely to support the electricity emissions abatement program.

The probit model estimating the mean and median WTP was computed employing the formula (Hanemann 1984): 
Table 2. Explanatory variables for probit regression

\begin{tabular}{|c|c|c|c|}
\hline Variable & Description & Mean & $\mathrm{SD}$ \\
\hline Bid $(€)$ & Price increase requested & 15.77 & 9.64 \\
\hline Age $(y r)$ & Age of individual & 44.74 & 14.82 \\
\hline Mediterranean & $=1$ if region of residence is Mediterranean or Andalucian; 0 otherwise & 0.328 & 0.47 \\
\hline Inland & $=1$ if region of residence is not on the coast & 0.272 & 0.446 \\
\hline MidIncome & $=1$ if income is between $€ 1500$ and 2999 & 0.169 & 0.376 \\
\hline HighIncome & $=1$ if income is $€ 3000$ or above & 0.059 & 0.236 \\
\hline ElectricBill & Monthly electricity bill & 15.880 & 27.677 \\
\hline
\end{tabular}

Table 3. Willingness to pay (WTP) regression: probit results. LR: likelihood ratio

\begin{tabular}{|lccrc|}
\hline WTP variable & Coefficient & SE & $z$ & $\mathrm{p}>|z|$ \\
\hline Bid & -0.0247 & 0.0088 & -2.79 & 0.005 \\
Age & -0.0153 & 0.0060 & -2.55 & 0.011 \\
Mediterranean & 0.4270 & 0.2087 & 2.05 & 0.041 \\
Inland & 0.2721 & 0.2127 & 1.28 & 0.201 \\
ElectricBill & -0.0034 & 0.0031 & -1.10 & 0.270 \\
Constant & 1.300 & 0.3593 & 3.62 & 0.000 \\
N & 233 & & & \\
LR & 19.61 & & & \\
p-value & 0.0065 & & & \\
\hline
\end{tabular}

$$
\mathrm{WTP}=\frac{-\tilde{\alpha}}{\tilde{\beta}}
$$

where $\widetilde{\alpha}$ represents the term known as the grand constant, i.e. the sum of the products of the means of the explanatory variables times their associated coefficients, and $\widetilde{\beta}$ is the coefficient associated with the 'Bid' amount.

\section{RESULTS AND POLICY IMPLICATIONS}

Mean/Median WTP per household was estimated to be about $€ 29.90 \mathrm{mo}^{-1}$, calculated from the probit model. The $95 \%$ confidence interval was estimated using the jackknife technique. When compared to current electricity prices (an average payment of around $€ 40 \mathrm{mo}^{-1}$ ), this monthly figure is quite high. This can be explained in several ways, but primarily by the fact that climate change was particularly salient at the time of the survey, due to the forthcoming Copenhagen summit played a role. It was also important that the higher initial payment was seen as a temporary phenomenon that could end by 2020, when the cost of renewable energy could fall due to learning effects. In any case, the result is consistent with the attitudes expressed by Spanish citizens in other opinion polls (see Section 1) and could justify the introduction of pricing instruments in climate-change policies. It is clear, though, as observed in actual Spanish policy making and in the conclusions of the focus groups in our present research, that the acceptance of pricing instruments is closely contingent on the definition and implementation of climate-change policies.

The results also show clear geographical differences with respect to support for this green electricity program. In particular, individuals residing in the Mediterranean and southern areas are more likely to be willing to pay higher electricity prices to prevent climate-change effects than those living in northern Spain.

Our results could also be employed to calculate the total societal WTP for the green electricity program, by multiplying the probit mean WTP by the number of Spanish households (as provided by the Instituto Nacional de Estadística [INE], 2001, available at: www. ine.es/inebmenu/mnu_cifraspob.htm). Given that our WTP question was formulated employing electricity prices as the payment vehicle, mean social WTP per month amounts to $€ 425$ million $\mathrm{yr}^{-1}$ for this electricity program. In this sense, the fact that Spanish society is willing to pay such a significant amount may facilitate adoption of renewable technologies. This resembles the conclusions by Longo et al. (2008), who in their UK analysis showed that the WTP for green policies may be sufficient to internalize the current social costs of energy production.

Acknowledgements. The authors are grateful for the comments and suggestions by the editor and 3 anonymous reviewers. Funding from the Spanish Ministry of Science and Innovation (Projects ECO2009-14586-C2-01 and ECO200914586-C2-02) and the FEDEA is also acknowledged. The usual disclaimer applies.

\section{LITERATURE CITED}

Berrens RP, Bohara AK, Jenkins-Smith HC, Silva CL, Weimer DL (2004) Information and effort in contingent valuation surveys: application to global climate change using national internet samples. J Environ Econ Manag 47: 331-363 
Brouwer R, Brander L, Van Beukering P (2008) A convenient truth: air travel passengers' willingness to pay to offset their $\mathrm{CO}_{2}$ emissions. Clim Change 90:299-313

Cameron T (2005a) Updating subjective risks in the presence of conflicting information: an application to climate change. J Risk Uncertain 30:63-97

Cameron $\mathrm{T}$ (2005b) Individual option prices for climate change mitigation. J Public Econ 89:283-301

> Carson RT, Mitchell RC, Hanenann M, Kopp RJ, Presser S, Rudd PA (2003) Contingent valuation and lost passive use: damages from the Exxon Valdez oil spill. Environ Resour Econ 25:257-286

Cole S, Brännlund R (2009) Climate policy measures: What do people prefer? Umea University, Mimeo. Available at: www. econ.umu.se/digitalAssets/7/7737_ues767.pdf (accessed on 8 August 2011)

Diaz-Rainey I, Ashton JK (2007) Characteristics of UK consumers' willingness to pay for green energy. Available from Social Science Research (SSRN), http://papers.ssrn. com/sol3/papers.cfm?abstract_id=1030530 (accessed on 8 August 2011)

Eurobarometer (2009) Europeans' attitudes towards climate change. Available at: http://ec.europa.eu/public_opinion/ archives/ebs/ebs_300_full_en.pdf (accessed on 8 August 2011)

Hanemann M (1984) Welfare evaluations in contingent valuation experiments with discrete responses. Am J Agric Econ 66:332-341

Hoyos D, Markandya A (2009) WTP for global and ancillary benefits of climate change mitigation: preliminary results. Paper presented at the 17th Annual Conference of the European Association of Environmental and Resource Economists (EAERE), Amsterdam, 24-27 June 2009

Johnson E, Nemet G (2010) Willingness to pay for climate policy: a review of estimates. University of WisconsinMadison. Available at: www.lafollette. wisc.edu/publications/ workingpapers/nemet2010-011.pdf (accessed on 8 August 2011)

Labandeira X, Labeaga JM (1999) Combining input-output analysis and micro-simulation to assess the effects of car-

Submitted: June 4, 2010; Accepted: January 26, 2011 bon taxation on Spanish households. Fiscal Studies 20: 305-320

Labandeira X, Labeaga JM, Rodríguez M (2004) Green tax reforms in Spain. Eur Environ 14:290-299

> Lee J, Cameron T (2008) Popular support for climate change mitigation: evidence from a general population mail survey. Environ Resour Econ 41:223-248

Leiserowitz A (2006) Climate change risk perception and policy preferences: the role of affect, imagery, and values. Clim Change 77:45-72

Li H, Berrens RP, Bohara AK, Jenkins-Smith HC, Silva CL, Weimer DL (2005) Testing for budget constraint effects in a National Advisory referendum survey on the Kyoto Protocol. J Agric Resour Econ 30:350-366

Longo A, Markandya A, Petrucci M (2008) The internalization of externalities in the production of electricity: willingness to pay for the attributes of a policy for renewable energy. Ecol Econ 67:140-152

Malka A, Krosnick JA, Langer G (2009) The association of knowledge with concern about global warming: trusted information sources shape public thinking. Risk Anal 29: 633-647

Spanish Agency of Meteorology (2010) Updated climate projections. Available at: www.aemet.es/es/elclima/cambio_ climat/proyecciones (accessed on 8 August 2011) (in Spanish)

Stedman RC (2004) Risk and climate change: perceptions of key policy factors in Canada. Risk Anal 24:1395-1406

> Viscusi W, Zeckhauser R (2006) The perception and valuation of the risks of climate change: a rational and behavioral blend. Clim Change 77:151-177

> Wiser R (2007) Using contingent valuation to explore willingness to pay for renewable energy: a comparison of collective and voluntary payment vehicles. Ecol Econ 62: 419-432

World Wide Views (2009) World wide views on global warming. Policy report by the Danish Board of Technology, Copenhagen. Available at: www.wwviews.org/files/ AUDIO/WWViews \% 20Policy\%20Report\%20FINAL\%20\%20Web\%20version.pdf (accessed on 8 August 2011)

Proofs received from author(s): August 9, 2011 